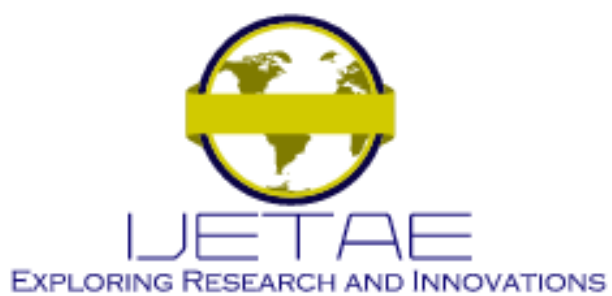

International Journal of Emerging Technology and Advanced Engineering

Website: www.ijetae.com (E-ISSN 2250-2459, Scopus Indexed, ISO 9001:2008 Certified Journal, Volume 12, Issue 01, January 2022)

Manuscript Received: 02 December 2021, Received in Revised form: 04 January 2022, Accepted: 10 January 2022

DOI: 10.46338/ijetae0122_12

\title{
Detection of Possible COVID-19 Cases using Thermal Imaging and a DRONE
}

\author{
Brian Meneses-Claudio ${ }^{1}$, Luis Nuñez-Tapia ${ }^{2}$, Witman Alvarado-Díaz ${ }^{3}$ \\ ${ }^{1,2,3}$ Universidad de Ciencias y Humanidades \& Av. Universitaria 5175, Los Olivos
}

\begin{abstract}
In December 2019, a series of cases of pneumonia caused by SARS-CoV-2 were identified in Wuhan (China), which was declared by the WHO as a pandemic on March $11^{\text {th }}, 2020$, because it caused enormous problems for the global public health due to its rapid expansion. In Peru it was only on March $6^{\text {th }}, 2020$, that the first case of COVID-19 was reported, therefore, the government took some measures to control the spread of the virus. A biosafety measure that is frequently used is taking the temperature with an infrared thermometer, which is not well seen by some specialists due to the error it has, therefore, it would not represent a safe measurement, as other measurement systems do. . In view of this problem, in this article a thermal image processing system was carried out to detect possible cases of patients with COVID-19, in such a way that the system performs a more accurate measurement of body temperature and can be implemented in any place, where this measurement is intended to be carried out, helping to combat the spread of the virus that currently continues to affect many people. Through the development of the system, tests were conducted with various people, obtaining a more accurate measurement of body temperature with an efficiency of $95 \%$ at $1 \mathrm{~m}$ between the drone and the person, in such a way that if it presents a body temperature above $37^{\circ} \mathrm{C}$ could be infected with COVID-19.
\end{abstract}

Keywords-- Thermal camera, COVID-19, Drone, MATLAB, WHO, Image processing.

\section{INTRODUCTION}

In December 2019, a series of cases of pneumonia caused by a new coronavirus were identified in Wuhan (China). This new coronavirus has different names: 2019-nCoV according to the WHO and SARS-CoV-2 according to the International Committee on Taxonomy of Viruses [1]. The World Health Organization (WHO) declared COVID-19 a pandemic on March $11^{\text {th }}, 2020$ [2]. Coronavirus disease 2019 (COVID-19), caused by the SARS-CoV-2 virus, is causing enormous global public health problems due to its rapid expansion. At the beginning, the main associated symptoms were influenza. However, Sars CoV2 infection was more dangerous than was reported in the early dates [3].
In Peru it was only on March $6^{\text {th }}, 2020$, that the first case of COVID-19 was reported. The government took steps recommended by the World Health Organization to reduce and control the spread of the virus. These include suspension of educational work, border closures, and compulsory social isolation [4]. The COVID19 pandemic in Peru reported 28,699 cases and 782 deaths on April 27, 2020, with the regions of Lima, Lambayeque, Loreto, and Piura, the ones that presented the greatest difficulty in managing this disease [5].

Likewise, with respect to the biosafety measures applied by the nursing staff during the hospital stay of patients with COVID -19 , it is evidenced that $50 \%$ of those evaluated consider that the measures stipulated by the MINSA regarding to the care of patients with COVID - 19, 36.7\% indicated that almost always, $10 \%$ sometimes and $3.3 \%$ consider that it never applies [6]. While it is true, most nursing personnel comply with the biosafety measures, but it is necessary to give them support to treat the person before the virus worsens the health of the infected person, in addition to being able to prevent the spread of the virus. The most frequently used biosafety measure is taking the temperature and the application of alcohol gel on the hands, although this measure is not well seen by some specialists due to the error that the infrared thermometer has [7], therefore, it would not represent a safe measurement, as other measurement systems do [8].

The objective of this research work is to conduct a thermal image processing system to detect cases of patients with COVID-19, in such a way that it has a more accurate measurement of people's body temperature unlike infrared thermometers that they are commonly used, helping to reduce the number of infections.

For the elaboration of the system, a drone was used that will take photos with a thermal camera of different people and that, through the image processing developed in MATLAB, indicates the body temperature. The MATLAB mathematical software allows us to perform numerical calculations with vectors and matrices and is especially useful for image processing since it allows us to manipulate images. 


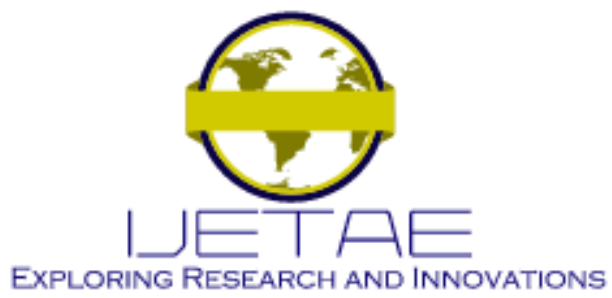

International Journal of Emerging Technology and Advanced Engineering

Website: www.ijetae.com (E-ISSN 2250-2459, Scopus Indexed, ISO 9001:2008 Certified Journal, Volume 12, Issue 01, January 2022)

In section II, a review of the literature was performed. In section III, the methodology will indicate the electronic part and design of the system. In section IV, the results that are generated according to the tests conducted with the system design will be presented. In section $\mathrm{V}$ the discussion will be presented, where the importance of this work with respect to other works conducted will be indicated. Finally, in section VI, the conclusion and recommendation obtained from the design of the system will be presented.

\section{LITERATURA REVIEW}

This frequently used biosafety measure is not reliable, unlike automated temperature measurement systems. For example: In [9], the author identified that studies based on thermography for the detection of any anomaly in the breasts are still in the process of acceptance and validation, in such a way that those specialists who use these systems do not clearly interpret the results and this would lead to a poor PR diagnosis, which is why he proposed to design a methodology to extract characteristics in thermal images using different statistical analysis techniques to detect abnormalities in breasts. The proposed method consists of using the FLIR SC620 thermal camera, a temperature sensor, using some digital image processing techniques using MATLAB software, Otsu thresholding method. Obtaining as a result an efficiency of $94.5 \%$, concluding that the elaboration of a segmentation method of the region of interest automatically, turned out to be good with prospects for improvement.

In [10], the authors identified that the JIR-1136F38 Camera is a thermal camera, which is at a disadvantage compared to high-cost cameras due to the fact that it does not have an automatic focus system and that it does not have an adequate focus. of a high-quality thermographic image and not measuring the temperature accurately, that is why they proposed to make an automatic focus system for a thermal camera, using image processing in MATLAB. The proposed method consists of using a JIR-1136F38 thermal camera, a DC Micro Motor to conduct the automatic focus process, can Be module for wireless communications, an ATmega 16 Microprocessor, digital image processing with MATLAB software. Obtaining as a result an efficiency of $97.5 \%$, concluding that the designed focus system guarantees a correct automatic focus, achieving a particularly good definition of the images taken and presenting an advantage in terms of cost compared to other cameras with automatic focus lenses.
In [11], the authors identified that the most effective methods for the diagnosis of COVID-19 are computed axial tomography (CT) image analysis and laboratory medical evaluations such as the polymerase chain reaction test ( PCR), the only disadvantage is that these traditional methods are very expensive and that implied that the lowermiddle class population does not have access to these detection tests, which is why they proposed to perform an analysis of X-ray images of Covid- 19 through artificial neural networks. The proposed method consists of using technological tools, which is why they conducted a machine learning model for the analysis of X-ray images for the detection of Covid-19 through convolutional neural networks. The algorithm was conducted in the Python programming language with the use of the Google Collaboratory cloud development environment. Through the public access repositories of GitHub and Kaggle, databases of chest X-ray images of patients with Covid-19 and normal (healthy) patients were collected to generate a dataset with training and validation images. Obtaining as a result an efficiency of $99.29 \%$, Concluding that the use of a development environment in the cloud provides the resources and sufficient packages to develop machine learning models when there is no computer with GPU and RAM memory to store and run. instructions.

In [12], the authors identified that COVID-19 damages the lungs of those who suffer from it, complicating their health because the lung is the respiratory system that allows us to breathe, so people die from lack of oxygen. Also, to leave sequelae to those people who managed to recover from this complicated disease since their lungs are damaged, that is why they proposed to make a tool for the automatic detection of COVID-19 lesions found in CT scans of the lungs. The proposed method involves an application created on the MATLAB platform in which the captured topographies can be viewed in different planes, with the option of segmenting the lungs or COVID-19 lesions, observing any of these in $3 \mathrm{D}$ and / or calculating the volume of these. Obtaining as a result an efficiency of $98.7 \%$, concluding that the algorithm was successful, since it can segment the injury and providing information to the medical professional about the condition of the patient in question in any of the established cases (mild, moderate, and severe case). 


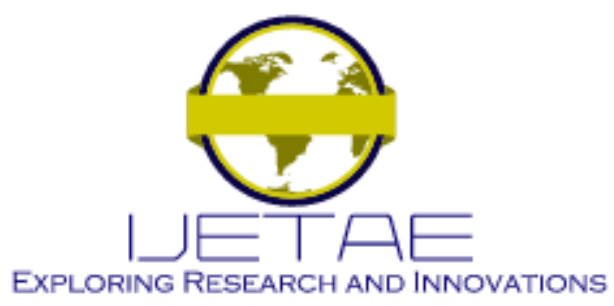

International Journal of Emerging Technology and Advanced Engineering

Website: www.ijetae.com (E-ISSN 2250-2459, Scopus Indexed, ISO 9001:2008 Certified Journal, Volume 12, Issue 01, January 2022)

In [13], the author identified that an effective solution for COVID-19 has not yet been found and that only the recommendations of health authorities and organizations should be followed, which are the use of masks, maintain two meters of social distance, frequent hand washing, avoid frequent mouth or nose contact. Of all these measures, social distancing is something that cannot be controlled correctly, which is why it was proposed to implement a social distancing recognition system as a preventive measure for COVID-19 using Deep Learning. The proposed method consists of using the YOLO version 3 object detection model trained with the COCO image set, obtaining as a result an accuracy of $80 \%$, concluding that the system correctly detects social distancing, and that Yolo was also highly effective in the detection of people with quite high scores in each detection.

In [14], the authors identified that currently with this pandemic, many people do not comply with the biosafety protocols, which is the use of the mask to circulate on the streets or visit a shopping center, therefore, these people do not know The importance of wearing a mask as it prevents the COVID-19 virus from continuing to spread, which is why they proposed to make an artificial intelligence application to monitor the use of protective masks. The proposed method consists of creating a web application that allows monitoring the use of the protective mask in public environments. Using the Flask framework, in the Python language, the application has a control panel that helps to visualize the data obtained. The detection process uses the Haar Cascade algorithm to classify faces with and without protective masks. Obtaining as a result an efficiency of $97.5 \%$, concluding that a web application has been developed that allows detecting and registering images of people's faces that do not wear more veneers, an application that can be easily implemented in low-cost devices.

\section{Methodology}

In this part, the flow diagram of the thermal image processing system will be made to detect cases of patients with COVID-19 and the electronic part that makes up the system. With this system, the person's body temperature will be measured and observed if they have a fever, which is a common symptom of COVID-19.

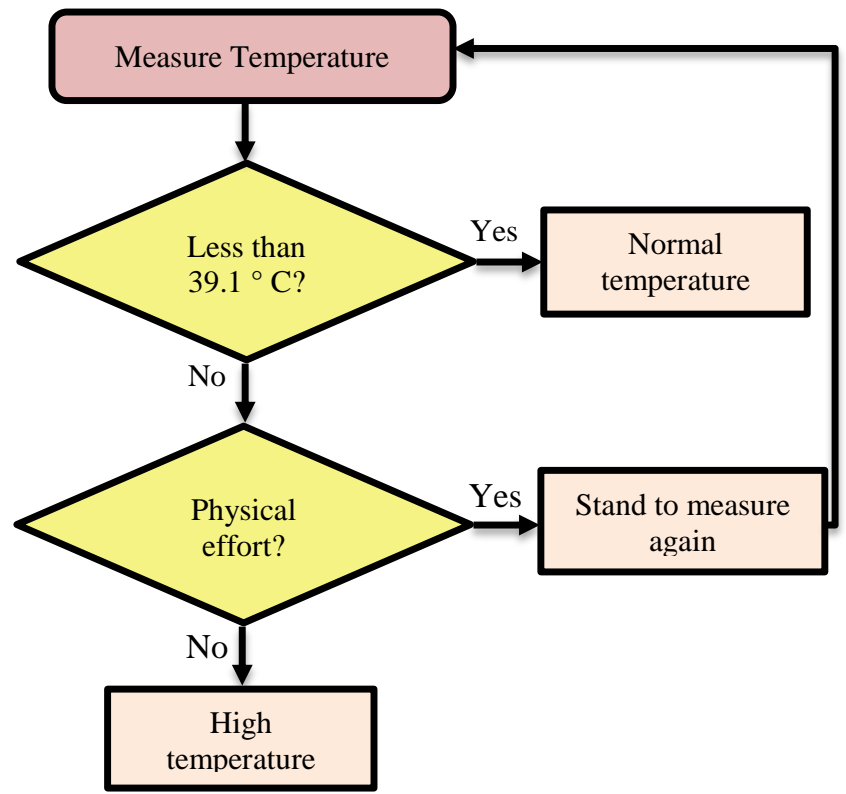

Fig. 1. Detection System Flow Chart

\section{A. Drone potensic $T 25$}

The potensic T25 drone as shown in figure 2 , is an unmanned aerial device that will allow the person to take a photo and subsequently analyze the body temperature with the help of the thermal camera. This device has the following characteristics [15]:

TABLE 1

CHARACTERISTICS OF THE DRONE

\begin{tabular}{|c|c|}
\hline \multicolumn{2}{|c|}{ Characteristics of the Potensic T25 Drone } \\
\hline Camera & FHD of 1080P \\
\hline Adjustable angle & $0-90^{\circ}$ \\
\hline Video Capture & High Quality \\
\hline Flight height & 300 meters \\
\hline Battery life & $3.7 \mathrm{~V} 1000 \mathrm{mAh}$ \\
\hline
\end{tabular}




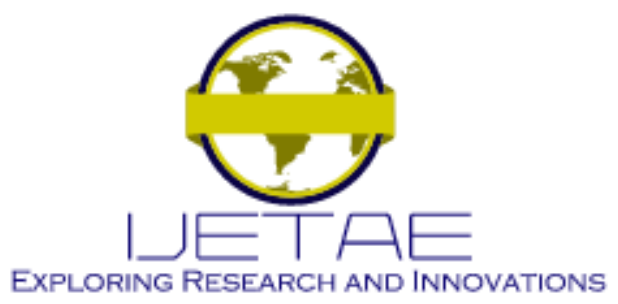

International Journal of Emerging Technology and Advanced Engineering

Website: www.ijetae.com (E-ISSN 2250-2459, Scopus Indexed, ISO 9001:2008 Certified Journal, Volume 12, Issue 01, January 2022)

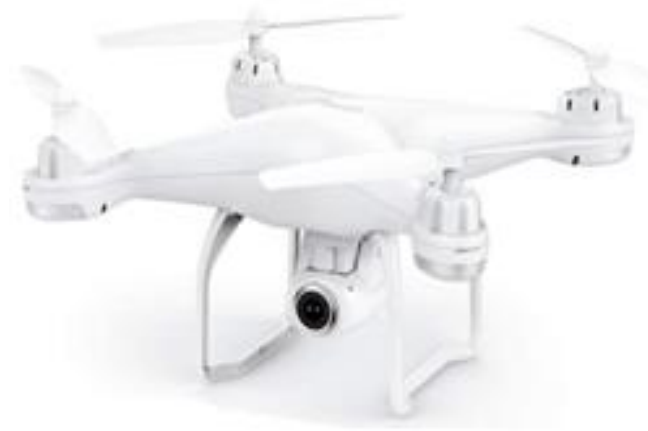

Fig. 2 Drone Potensic T25

\section{B. FLIR ONE Pro}

The FLIR ONE Pro is a thermal camera that with the help of the drone, will take photos of people according to their corresponding height. Figure 3 shows the FLIR ONE Pro that has 2 lenses, the upper lens is from the normal camera and the lower lens is from the thermal camera. In addition, it is compatible with Android and IOS mobile devices and has its own software to process thermal images. This device has the following characteristics [16]:

TABLE 2

FLIR ONE Pro CharaCteristics

\begin{tabular}{|c|c|}
\hline \multicolumn{2}{|c|}{ Characteristics of the FLIR ONE Pro } \\
\hline Dimension & $68 \times 34 \times 14 \mathrm{~mm}$ \\
\hline Weight & 36.5 grams \\
\hline Temperature range & $-20^{\circ} \mathrm{C}$ to $-400^{\circ} \mathrm{C}$ \\
\hline Thermal resolution & $160 \times 120$ \\
\hline Operating distance & 1.8 meters maximum \\
\hline Compatibility & Android and IOS \\
\hline
\end{tabular}

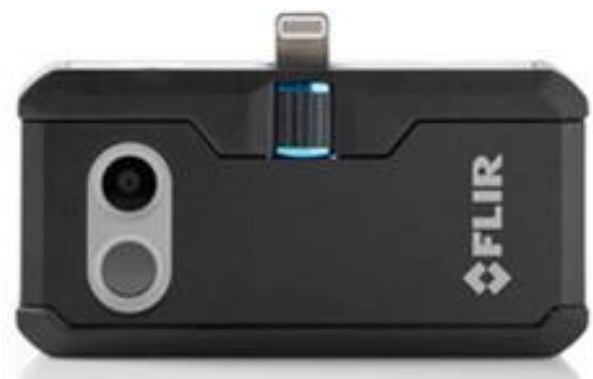

Fig 3 FLIR ONE Pro Thermal Camera

\section{Distance between the drone and the person}

The distance in which the drone must be in front of the person is a key factor that must be considered. To have knowledge of the exact value of the distance, we have been guided by the physical distance that people must avoid getting and spreading the virus, this value is 1 or 2 meters, so some specialists have indicated that the physical distance should be greater than 1 meter. Therefore, after conducting some tests to determine the distance in which the drone must be in front of the person, we came to determine that the numerical value of the distance is 1 meter, as shown in figure 4 and in figure 5 .

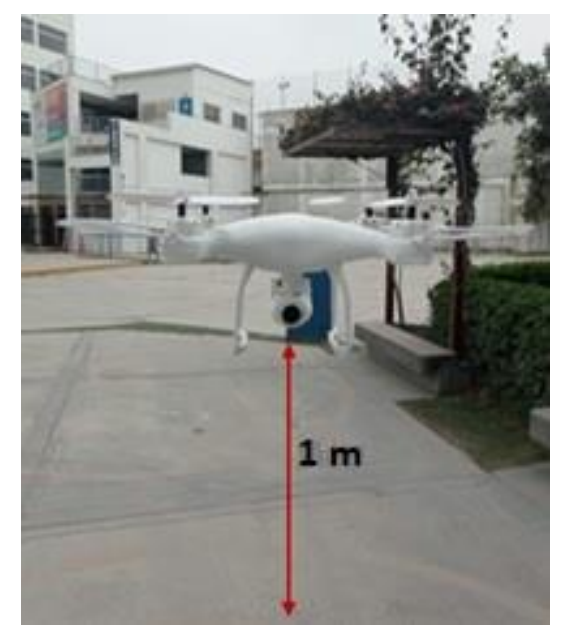

Fig 4 Distance of the Drone in front of the person

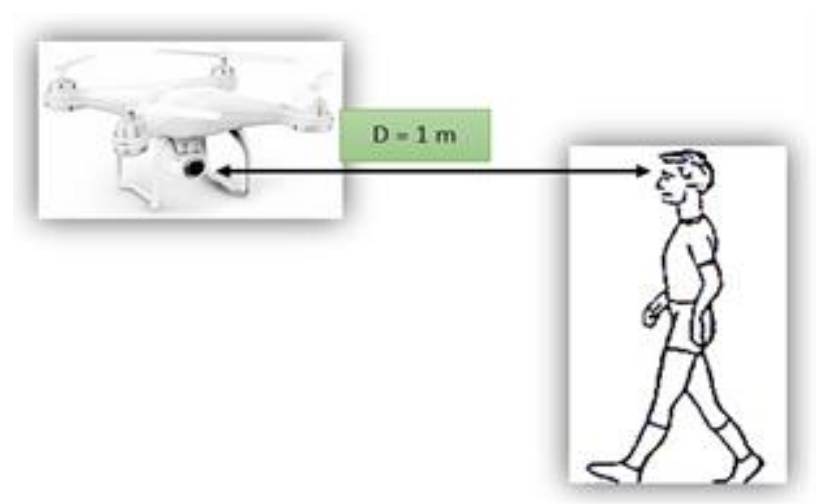

Fig. 5 Approach of the drone towards the person

\section{Average drone height}

The average height in which the drone could be is 140 to $185 \mathrm{~cm}$, this can be done by the angular adjustment that the drone has, which goes from $0^{\circ}$ to $90^{\circ}$. 


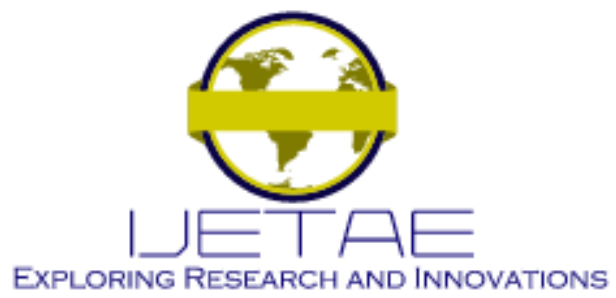

International Journal of Emerging Technology and Advanced Engineering

Website: www.ijetae.com (E-ISSN 2250-2459, Scopus Indexed, ISO 9001:2008 Certified Journal, Volume 12, Issue 01, January 2022)

This value range was established because it is the average height of the Peruvian population, $165.3 \mathrm{~cm}$ for men and $152.9 \mathrm{~cm}$ for women [17]. For example, in figure 6 the drone is observed at a height of $172 \mathrm{~cm}$ and in figure 7 the drone is observed at a height of $184 \mathrm{~cm}$.

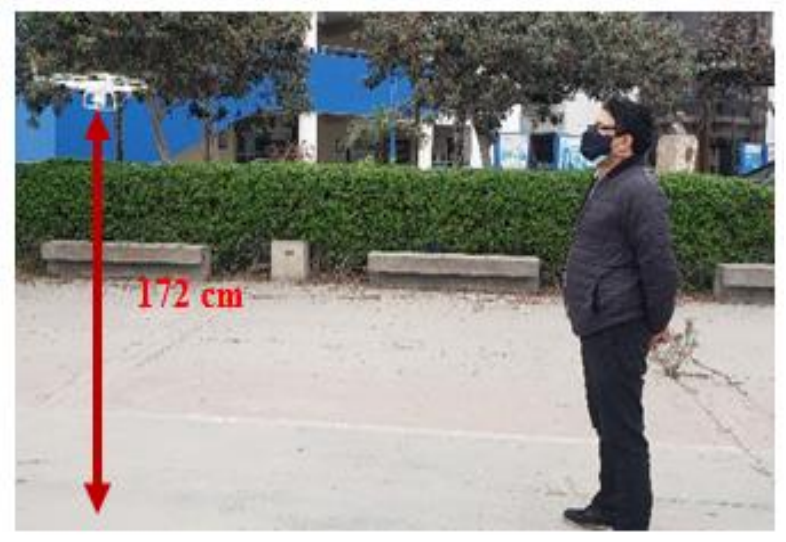

Fig 6 Drone $172 \mathrm{~cm}$ high

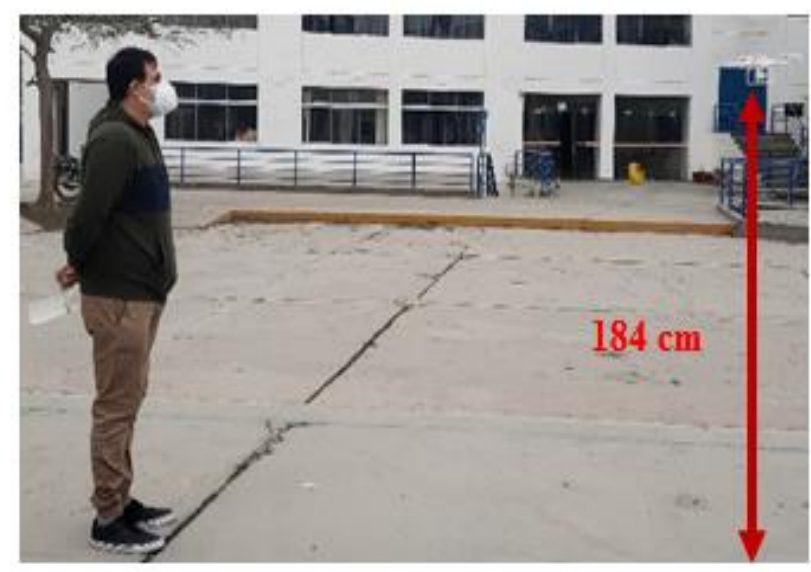

Fig 7 Drone $184 \mathrm{~cm}$ high

In addition, it should be noted that the place where the images were taken and the present research work was conducted is the Universidad de Ciencias y Humanidades, this to guarantee the health of individuals, also following the biosafety protocols demanded by the university and the Peruvian state.

\section{PRocesamiento De ImÁgenes}

After identifying the average height of the Peruvian in addition to the characteristics of the thermographic camera and DRONE, we will proceed to the explanation of the image processing, where the step by step of the image will be specified, because the area of interest is the front of the individual, in addition that the DRONE must be operative for the collection and subsequent processing of images [18].

The MATLAB software was used for image processing, that is why the collected image is first declared that is in RGB, it should be noted that before being entered into the software the image goes through a pixel range arrangement treatment, it means that the pixels are rearranged to the range of $15^{\circ} \mathrm{C}$ to $40^{\circ} \mathrm{C}$, being a range inside and outside the normal standard in order to identify abnormalities. The first step for image processing is the conversion from RGB (red, green, blue) to grayscale because this way it will not spend many resources during image processing, the internal formula is the following [19]:

$$
0.2989 * R+0.5870 * G+0.114 * B
$$

This step is conducted because it will give us values within the range of $0-255$ in two dimensions, facilitating the processing of pixel matrices, in addition to facilitating the processing and application of filters.

After having the image in grayscale, a conversion process called "temperature mapping" is required, which consists of converting such pixels to temperature ranges, this to identify the pixels with higher temperatures and thus they are sectorized, For this, the following mathematical formula will be used, it should be noted that the software does all of this automatically [20]:

Map $=(($ Pixel_Image - FromLow $) *($ ToHigh- ToLow $) /$ $($ FromHigh - FromLow $))+$ ToLow

Where the FromLow and FromHigh are the gray scale that is from 0 to 255 and ToLow and ToHigh are the temperature scale that had been previously indicated that goes from $15^{\circ} \mathrm{C}$ to $40^{\circ} \mathrm{C}$, finally Pixel_Image is the pixel of the image. 


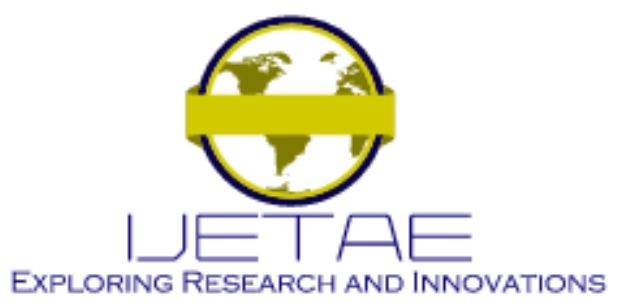

International Journal of Emerging Technology and Advanced Engineering

Website: www.ijetae.com (E-ISSN 2250-2459, Scopus Indexed, ISO 9001:2008 Certified Journal, Volume 12, Issue 01, January 2022)

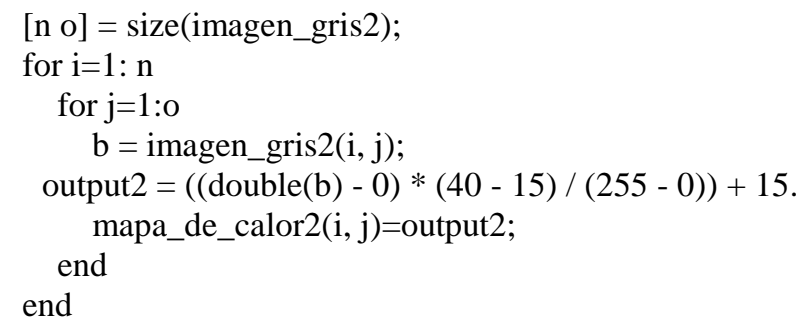

First, the size of the image is declared because we will make a complete tour of the image, then two loops are applied so that it takes all the pixels in both dimensions. In addition, we declare a variable with the formula (2), and thus convert each pixel from grayscale to the temperature scale, we will do this with the entire image.

Then, the detection of the pixels with abnormal temperatures will be carried out, for this the following programming was used [21]:

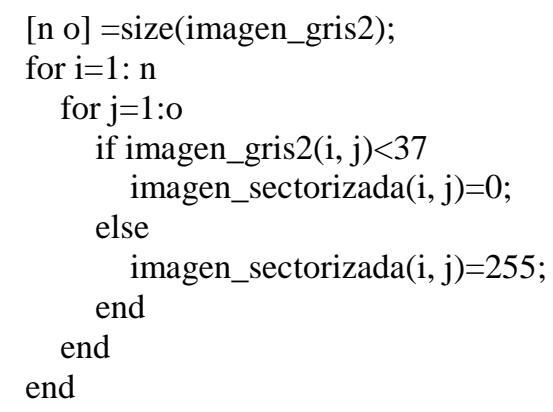

As the reader can identified in the programming, first as well how the above programming is performed the image size display and the full scan loop of all the pixels in the image. The sentence of pixels less than $37^{\circ} \mathrm{C}$ was used, as normal pixels, it will also be indicated that, if you obtain those pixels, paint it white if those that are outside that range are abnormal pixels, black; this to obtain an image where we only obtain abnormal pixels and verify if the individual has a possible suspicion of high temperatures, concluding in a possible case of COVID-19.

Also for aesthetic reasons, the area of pixels of interest was painted correctly with the following programming [22]: 


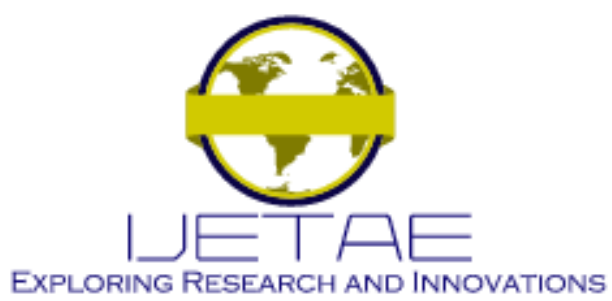

International Journal of Emerging Technology and Advanced Engineering

Website: www.ijetae.com (E-ISSN 2250-2459, Scopus Indexed, ISO 9001:2008 Certified Journal, Volume 12, Issue 01, January 2022)

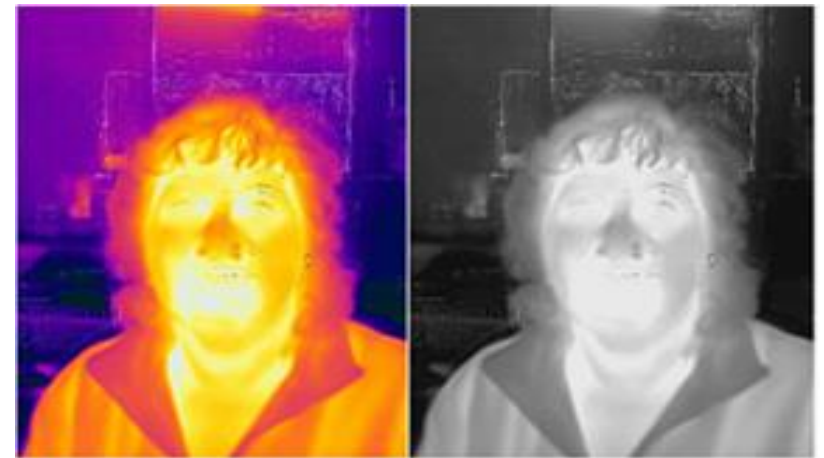

(a)

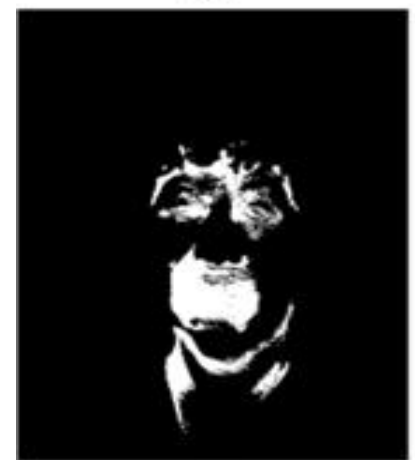

(c)

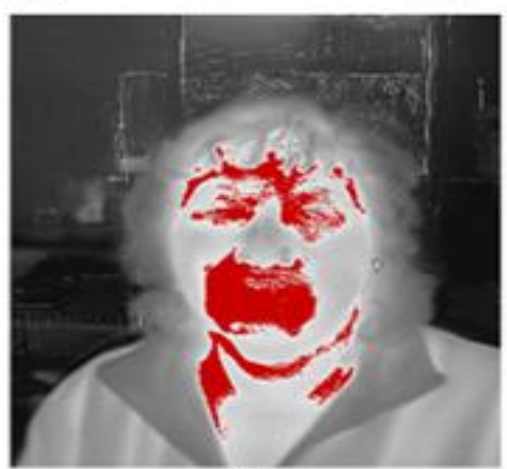

(e)

Fig. 8 (a) Thermal Image. (b) Grayscale Image. (c) Sectorized image of the area of interest. (d) Zone of interest with color style. (d) Overlay of the area of interest on the grayscale image.

\section{RESULTS}

The thermal images were collected at the Universidad de Ciencias y Humanidades, in addition, all the biosafety protocols regulated by the Peruvian state and the university were followed, in addition all the images were collected following established characteristics so that during image processing there are no differences or erroneous pixel matrix treatment problems.
Table 2 will show the protocols that were followed for the collection of thermal images.

TABLE 3

Characteristics OF THE THERMAL IMAgE

\begin{tabular}{|c|c|}
\hline \multicolumn{2}{|c|}{ Thermal Imaging } \\
\hline Distance & 0.8 meter to 1 meter \\
\hline Temperature Range & $15^{\circ} \mathrm{C}-40^{\circ} \mathrm{C}$ \\
\hline Inflection Temperature & $>37^{\circ} \mathrm{C}$ \\
\hline Area of Interest & $\begin{array}{ll}\text { - } & \text { Front } \\
\text { - } & \text { Mask } \\
\text { - } & \text { Neck }\end{array}$ \\
\hline Connected Device & $\begin{array}{c}\text { Redmi Note } 9 \text { - Anchored to } \\
\text { a DRONE }\end{array}$ \\
\hline Rest time before study & 0 minutes \\
\hline $\begin{array}{c}\text { Thermal camera operating } \\
\text { time }\end{array}$ & 50 minutes \\
\hline
\end{tabular}

In Figure 9, the reader can identify the results of the research work, where in section (a) we have the thermal image captured of the individuals who were part of the study, in section (b) the sectorization and verification of pixels in abnormal temperatures greater than $37^{\circ} \mathrm{C}$, being considered a possible COVID-19 case due to the high temperature obtained in the areas of interest mentioned in Table III, finally in section (c) it is the sectorization superimposed on the gray scale image to obtain a better visualization of the affected area as well as indicative of the disease. This research work had 27 individuals who were part of the study, made up of university students, university professors, cleaning personnel, security personnel and logistics personnel of the Universidad de Ciencias y Humanidades, of which $7(25.93 \%)$ presented ranges of temperature between $37^{\circ} \mathrm{C}-38^{\circ} \mathrm{C}$ in the area of interest, 2 (7.41\%) had ranges higher than $38^{\circ} \mathrm{C}$, both being almost confirmed cases of COVID-19 or presenting high temperature ranges, $14(51.85 \%)$ did not present high temperature ranges were within the allowed range being between $30^{\circ} \mathrm{C}$ to $36.5^{\circ} \mathrm{C}$ and finally $4(14.81 \%)$ presented abnormal ranges but the distance between the pixels was between $0.4 \mathrm{~mm}$ to $0.7 \mathrm{~mm}$, thus providing a possible suspicion of COVID-19 in early stay. 


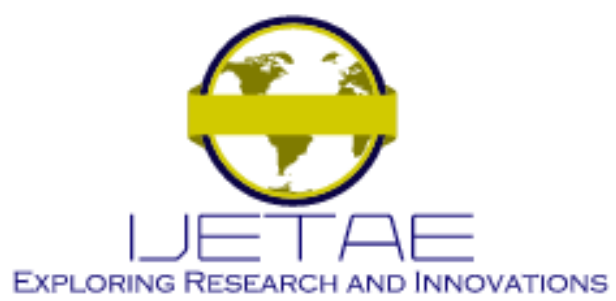

International Journal of Emerging Technology and Advanced Engineering

Website: www.ijetae.com (E-ISSN 2250-2459, Scopus Indexed, ISO 9001:2008 Certified Journal, Volume 12, Issue 01, January 2022)

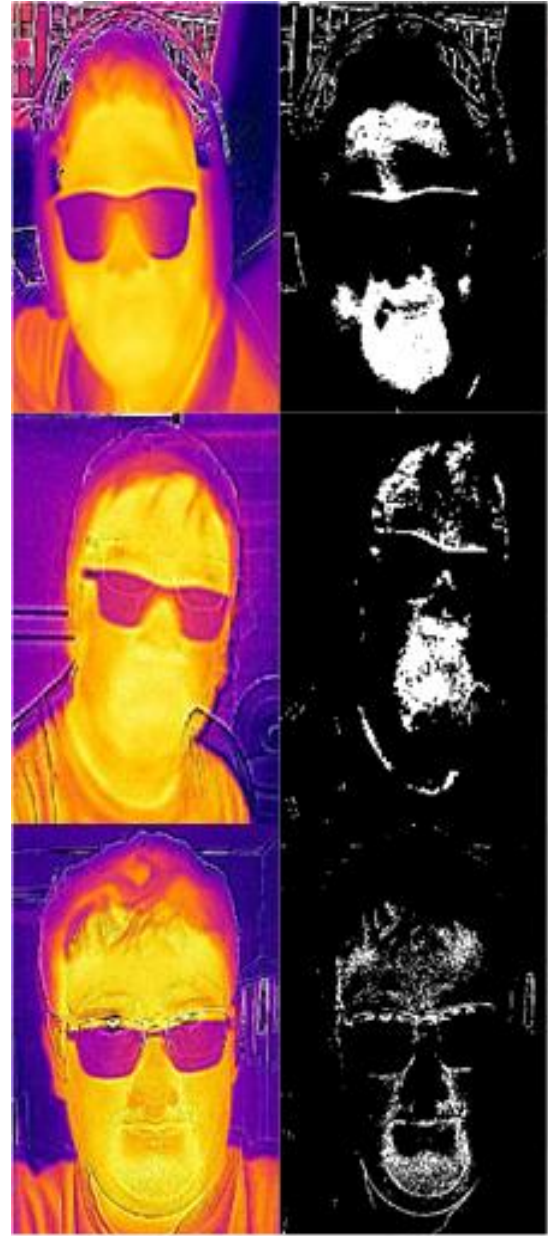

(a)

(b)

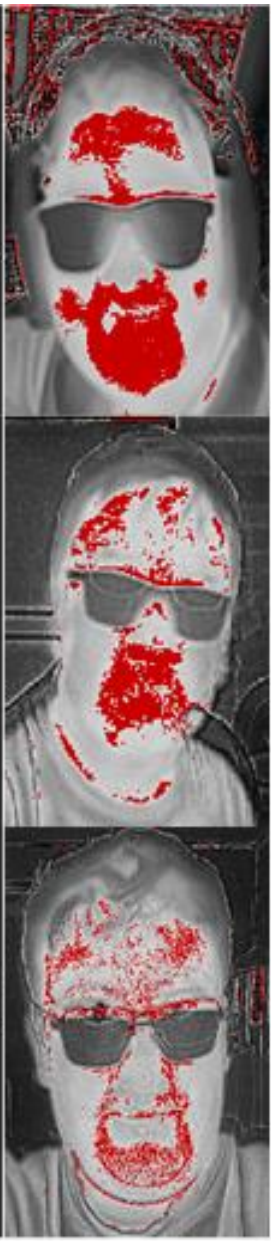

(c)

Fig 9 (a) Thermal Image. (b) Area of Interest of the affected area. (c) Overlay of abnormal pixels on the grayscale image.

\section{DISCUSSION}

The articles developed on COVID-19 have the same purpose, which is to provide solutions to avoid contagion between people and control the spread of the virus that currently continues to affect several countries.

A research work similar to this research work has not yet been developed, therefore, it differs from several articles, among them we have the research work done by [10], where the authors propose to develop an automatic focus system for a thermal camera, using image processing in MATLAB. Although, it is true, they obtained a result of $97.5 \%$ efficiency, but this system did not perform tests with measurement once the thermal camera was improved, so it does not generate reliability.
We also have the research work developed by [11], where the authors propose to develop an analysis of X-ray images of COVID-19 through artificial neural networks. Obtaining a result of $99.29 \%$ efficiency, so this research work meets the objective that is to help people to rule out if they have any symptoms of the virus.

We also have the research work developed by [12], where the authors propose to develop a tool for the automatic detection of COVID-19 lesions found in Computed Tomography scans of the lungs. Although it is true, they obtained a result of $98.7 \%$ efficiency, but this system does not indicate if the person has the virus in its body, it only performs the evaluation when the person is already healed from the virus.

We also have the research work done by [13], who proposed to implement a social distancing recognition system as a preventive measure for COVID-19 using Deep Learning, this research work only shows social distancing between people. While it is true, they had a result of $80 \%$, but this system cannot detect if a person may have a fever.

We also have the research work developed by [14], where the authors proposed an application of artificial intelligence to monitor the use of protective masks. Although it is true, they obtained a result of $97.5 \%$ efficiency, but this system does not specify whether the person complies with the physical distancing, it only focuses on the use of a mask.

\section{CONCLUSION}

It is concluded that the application of this system is very efficient. This would help reduce infections between people because it will detect people's body temperature and if there is an abnormal temperature it will give a warning.

It is concluded that this system can be used in various places, because it has the necessary equipment to develop in the best way anywhere.

It is concluded that this system is very safe and reliable for people because there will be no physical contact between them, therefore, there is no risk of being infected by the virus.

It is concluded that the MATLAB software was an especially valuable tool for the present system, due to its mathematical characteristics that can be developed using this software. While it is true, the programming in this software is not as friendly unlike other programming, but it is worth developing.

As work in the future, a physical distancing detector will be added to this system to help prevent infections that are currently on the rise. 


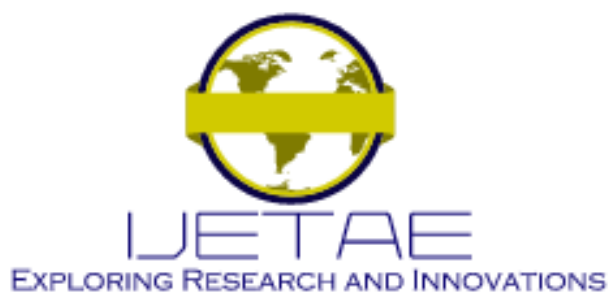

International Journal of Emerging Technology and Advanced Engineering Website: www.ijetae.com (E-ISSN 2250-2459, Scopus Indexed, ISO 9001:2008 Certified Journal, Volume 12, Issue 01, January 2022)

This would prevent the spread of the virus. In addition, it will be evaluated at the Universidad de Ciencias y Humanidades in students, teachers, and workers.

It is recommended to consider the characteristics specified for the operation of the system, among them we have the distance in which the drone will be in front of the person, it cannot be extremely far since it will not take the photo of excellent quality, nor very close. which could cause physical injury to the person with the propellers of the drone.

\section{REFERENCES}

[1] E. Zevallos Santillan, J. Cruzado Burga, and R. Avalos Rivera, "COVID-19; Perú a los 100 días, breve observación de una pandemia que pone en serios aprietos a la salud pública mundial," Rev. Medica Hered., vol. 31, no. 4, pp. 287-289, Jan. 2020, doi: 10.20453/RMH.V31I4.3865.

[2] F. Jirjees, Y. Dallal Bashi, and H. Al-Obaidi, "COVID-19 Death and BCG Vaccination Programs Worldwide," Tuberc. Respir. Dis. (Seoul)., vol. 84, no. 1, pp. 13-21, Jan. 2021, doi: 10.4046/TRD.2020.0063.

[3] L. Bourouiba, "Turbulent Gas Clouds and Respiratory Pathogen Emissions: Potential Implications for Reducing Transmission of COVID-19," JAMA - J. Am. Med. Assoc., vol. 323, no. 18, pp. 1837-1838, May 2020, doi: 10.1001/JAMA.2020.4756.

[4] L. Albitres Flores, Y. Pisfil Farroñay, K. Guillen Macedo, R. Niño Garcia, and C. Alarcon Ruiz, "Perception of medical interns about the internship during the COVID-19 pandemic in Peru," no. 1, pp. 1-16, May 2020, doi: 10.1590/SCIELOPREPRINTS.301.

[5] C. Tello Ayllón, "Evolution of the COVID19 pandemic in the andean regions of Peru," An Fac med, vol. 81, no. 2, pp. 252-255, May 2020, doi: 10.15381/anales.v81i2.17774.

[6] M. Morales Arica, "Medidas de bioseguridad aplicadas por el personal de enfermería durante la estancia hospitalaria de los pacientes con COVID -19 del Hospital I EsSalud Sullana, 2020," Universidad César Vallejo, Piura - Perú, 2020.

[7] E. Villanueva, Fernámdez. M., E. Viano, and M. Amorín, "Fiabilidad en la medición de la temperatura corporal con un termómetro timpánico en pacientes geriátricos,” SCIELO, vol. 28 , no. 2, pp. 68-72, Jun. 2020.

[8] R. Hilario Quispe, "Efectividad del uso del termómetro digital versus el térmometro infrarrojo en el paciente pediátrico," Universidad privada Norbert Wiener, Lima - Perú, 2020.

[9] D. Sánchez Ruiz, "Procesamiento y análisis de imágenes térmicas para dominios médicos," Benemérita Universidad Autónoma de Puebla, Puebla - México, 2018.

[10] A. Rodas, A. Toapanta, and E. Rodriguez, "Sistema De Enfoque Automático Para Una Cámara Térmica, Usando Procesamiento De Imágenes En Matlab,” Rev. Politécnica, vol. 35, no. 2, pp. 1-1, Feb. 2015.

[11] K. Morocho Sande and D. Pulig Cesén, "Análisis de imágenes de rayos X de Covid-19 a través de redes neuronales artificiales," Universidad de Guayaquil. Facultad de Ciencias Matemáticas y Físicas. Carrera de Ingeniería en Sistemas Computacionales., Guayaquil - Ecuador, 2021.
[12] A. Estrada and E. Álvarez, "Herramienta para la Detección Automática de Lesiones de COVID-19 en Tomografías Computarizadas," Memorias del Congr. Nac. Ing. Biomédica, vol. 7, no. 1, pp. 125-132, Oct. 2020, doi: 10.24254/CNIB.20.16.

[13] W. S. Córdova Eras, "Implementación de un sistema de reconocimiento de distanciamiento social como medida preventiva para covid 19 usando deep learning," Machala: Universidad Tëcnica de Machala, Machala - Ecuador, 2020.

[14] F. Oliveira Teixeira, T. Donadon Homem, and A. Pereira Junior, "Aplicación de inteligencia artificial para monitorear el uso de mascarillas de protección," Rev. Científica Gen. José María Córdova, vol. 19, no. 33, pp. 205-222, Jan. 2021, doi $10.21830 / 19006586.725$.

[15] S. Sudha and S. Nagarajan, "Solar Charged Automated Drones Using Recognition Of The Institution In Zambia," J. Intell. Syst. Robot. Insights Transform., vol. 3, no. 1, 2019.

[16] B. Meneses Claudio, W. Alvarado Díaz, F. Flores Medina, N. Vargas Cuentas, and A. Roman Gonzalez, "Muscles Heating Analysis in Sportspeople to Prevent Muscle Injuries using Thermal Images," IJACSA) Int. J. Adv. Comput. Sci. Appl., vol. 10, no. 6 , 2019.

[17] C. Escobar Galindo, "Perfil antropométrico de trabajadores del Perú utilizando el método de escala proporcional," Ergon. Investig. y Desarro., vol. 2, no. 2, pp. 96-111, 2020.

[18] [18] L. Nuñez Tapia, B. Meneses Claudio, and W. Alvarado Díaz, "Design of a thermal imaging system to detect possible cases of COVID-19 patients,” Int. J. Emerg. Technol. Adv. Eng., vol. 11, no. 9, pp. 66-72, Sep. 2021, doi: 10.46338/JJETAE0921_08.

[19] B. Meneses Claudio, W. Alvarado Díaz, and A. Roman Gonzalez, "Detection of Suspected of Breast Cancer Using Thermal Images," Adv. Intell. Syst. Comput., vol. 1326 AISC, pp. 252-262, Oct. 2020, doi: 10.1007/978-3-030-68080-0_19.

[20] B. Meneses Claudio, W. Alvarado Diaz, and A. Roman Gonzalez, "Detection of suspicions of Varicose veins in the legs using thermal imaging," IJACSA) Int. J. Adv. Comput. Sci. Appl., vol. 10, no. 5, pp. 431-435, 2019, doi: 10.14569/IJACSA.2019.0100554.

[21] B. Meneses Claudio, W. Alvarado Díaz, F. Flores Medina, N. Vargas Cuentas, and A. Roman Gonzalez, "Detection of Suspicious of Diabetic Feet using Thermal Image," Int. J. Adv. Comput. Sci. Appl., vol. 10, no. 6, pp. 379-383, 2019, doi: 10.14569/IJACSA.2019.0100648

[22] M. Yauri Machaca, B. Meneses Claudio, A. Roman Gonzalez, and N. Vargas Cuentas, "Design of a Vehicle Driver Drowsiness Detection System Through Image Processing using Matlab," Proc. 2018 IEEE 38th Cent. Am. Panama Conv. CONCAPAN 2018, pp. 1-6, Dec. 2018, doi: 10.1109/CONCAPAN.2018.8596513.

[23] B. Meneses Claudio, W. Alvarado Diaz, A. Roman Gonzalez, and E. Zamora Villaorduña, "Implementation of a Wireless system for the processing and comparison of cerebral waves of patients with Amyotrophic Lateral Sclerosis through Matlab identifying their basic needs,” 2017 Chil. Conf. Electr. Electron. Eng. Inf. Commun. Technol. CHILECON 2017 - Proc., vol. 2017-January, pp. 1-7, Dec. 2017, doi: 10.1109/CHILECON.2017.8229671. 